\title{
Arboreal behaviour in the Stuart's burrowing snake Adelphicos veraepacis (Dipsadinae) in Baja Verapaz, Guatemala
}

\author{
MARTÍN VITERI ${ }^{1 *}$ \& CRISTINA ARRIVILLAGA ${ }^{2}$ \\ ${ }^{1}$ Universidad del Valle de Guatemala, Guatemala \\ ${ }^{2}$ Crees Foundation, Manu Biosphere Reserve, Peru \\ *Corresponding author e-mail: martinv90@gmail.com
}

A delphicos veraepacis Stuart, 1941 is a little known snake species that is endemic to the mountain regions of Guatemala, occurring only in Sierra de las Minas, Cuilco Mountains, Sierra de los Cuchumatanes and Sierra de Xucaneb (Acevedo et al., 2014). It inhabits cloud, rain and pine forests from 1,200 to 2,200 meters asl. Snakes in this genus are encountered infrequently due to their predominantly fossorial and terrestrial lifestyle. Consequently, there are few published observations of their ecology or natural history. According to the IUCN Red List, A. veraepacis is classified as vulnerable due to its restricted distribution and the associated threat of habitat loss. The cloud forests from the Verapaces region, where this snake was observed, are currently threatened owing to the increased cultivation of leatherleaf (Chamaedaphne calyculata) for export to Japan and Europe, pine plantations and intentional fires (Acevedo et al., 2014).

During the second week of September 2014, a field trip was made to Ranchitos del Quetzal, Purulha, Baja Verapaz $\left(15.215489^{\circ} \mathrm{N}, 90.219249^{\circ} \mathrm{W}, 1,682 \mathrm{~m}\right.$ asl). During a night time visual encounter survey at $21: 30 \mathrm{~h}$, a female $A$. veraepacis (Fig.1) was found approximately $3 \mathrm{~m}$ up a tree in a cloud forest habitat. Previous accounts of this genus have noted the behaviour of Adelphicos to be highly fossorial and terrestrial (Acevedo et al., 2014). However, arboreal behaviour has been recorded in a closely related species, A. quadrivirgatum. In this case, clutches of eggs were found $1.5 \mathrm{~m}$ above the ground in a termite nest (Pérez-Higareda \& Smith, 1989). Our observation was made in September but the egg laying season in $A$. veraepacis is reported to be from May to June (Campbell, 1998). While we have no evidence, it remains possible that the reproduction of this species is not seasonally restricted, and that the observed female specimen had laid eggs. Alternatively, facultative use of arboreal habitats while foraging has been described for numerous terrestrial and presumably fossorial snakes (Keller \& Heske 2000; Brown et al., 2018). Snakes of the genus Adelphicos are known to prey on earthworms and other invertebrates (Dos Santos et al., 2017; Stafford \& Meyer, 2000), so arboreal foraging remains a possibility.

\section{ACKNOWLEDGMENTS}

We thank Msc. Daniel Ariano for helping us with the identification of the snake and for taking us to this field

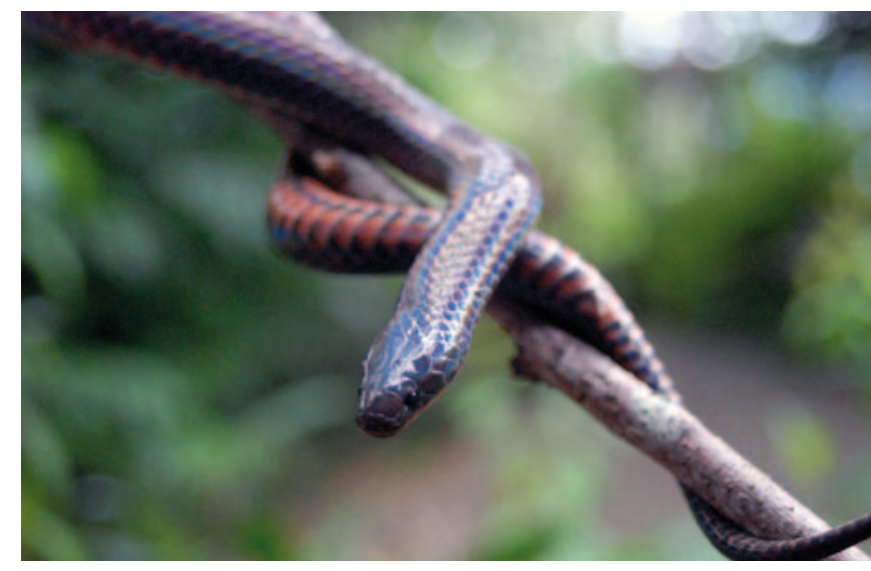

Figure 1. Photograph of the female $A$. veraepacis the day after it was observed $3 \mathrm{~m}$ up in a tree in the Ranchitos del Quetzal lodge, Baja Verapaz, Guatemala

Herpetology trip. We thank Tom Brown for reviewing and correcting the writing of this note and the staff from the Ranchitos del Quetzal lodge for always allowing us to conduct our research and field trips in the area.

\section{REFERENCES}

Acevedo, M., Ariano-Sánchez, D. \& Johnson, J. (2014). Adelphicos veraepacis. The IUCN Red List of Threatened Species 2014: e.T203338A2764216. http://dx.doi. org/10.2305/IUCN.UK.2014-1.RLTS.T203338A2764216. en. Downloaded on 21 March 2019.

Brown, T., Van den Burg, M., Maryon, D. F. \& Arrivillaga, C. (2018). Arboreality and diet in Pacific longtailed snakes, (Squamata: Dipsadidae), and a potential adaptive hypothesis for egg attendance Enulius flavitorques in Honduran leaf toed geckos, Phyllodactylus palmeus (Squamata: Phyllodactylidae). IRCF Reptiles \& Amphibians 25 (1): 31-34.

Campbell, J. A. (1998). Amphibians and Reptiles of Northern Guatemala, the Yucatán and Belize. Norman University of Oklahoma Press: 380 pp.

Dos Santos, M. M., da Silva, F. M., Hingst-Zaher, E., Machado, F. A., Zaher, H. E. D., \& Prudente, A. L. da C. (2017). Cranial adaptations for feeding on snails in species of Sibynomorphus (Dipsadidae: Dipsadinae). Zoology 120: 24-30. 
Keller, W.L. \& E.J. Heske. (2000). Habitat use by three species of snakes at the Middle Fork Fish and Wildlife Area, Illinois. Journal of Herpetology 34: 558-564.

Pérez-Higadera, G \& H. M. Smith. (1989). Termite nest incubation of the eggs of the Mexican colubrid snake, Adelphicos quadrivirgatus. Herpetological Review 20: 5-6.
Stafford, P.J. \& Meyer J.R. (2000). A Guide to the Reptiles of Belize. The Natural History Museum and Academic Press, $356 \mathrm{pp}$.

Accepted: 17 April 2019 